Penggunaan Pasta Ubi Kayu Sebagai Bahan Baku Pembuatan Cake - Yunieta, dkk Jurnal Pangan dan Agroindustri Vol.6 No.2: 1-12, April 2018

\title{
PENGGUNAAN PASTA UBI KAYU (Manihot esculenta Crantz) SEBAGAI BAHAN BAKU PEMBUATAN CAKE (KAJIAN TEKNIK PEMBUATAN CAKE DAN JENIS LEMAK)
}

\section{The Use of Cassava Paste (Manihot esculenta Crantz) as Cake Production Main Ingredient (Study of Cake Making Technique and Type of Fat)}

\author{
Mellinda Yunieta*, Aji Sutrisno \\ Jurusan Teknologi Hasil Pertanian, FTP - Universitas Brawijaya Malang \\ Jalan Veteran, Malang 65145 \\ *Penulis Korespondesi, Email: mellindayunieta@ymail.com
}

\begin{abstract}
ABSTRAK
Pengembangan bahan baku lokal pengganti terigu diperlukan untuk mengurangi impor gandum sebagai bahan baku cake. Penelitian ini menggunakan metode penelitian RAK yang disusun secara faktorial dengan faktor perlakuan teknik pembuatan cake, yaitu pengocokan kuning dan putih telur secara langsung (sponge cake) dan pengocokan kuning dan putih telur secara terpisah (chiffon cake) dan jenis lemak, yaitu margarin, minyak goreng, dan tanpa lemak. Hasil analisis ragam (ANOVA) menunjukkan bahwa perlakuan teknik pembuatan cake dan jenis lemak berpengaruh nyata terhadap volume pengembangan, kekerasan, warna $\left(L^{*}\right.$, $\left.a^{*}, b^{*}\right)$ namun tidak berpengaruh nyata terhadap kadar air dan ukuran pori. Hasil uji Friedman untuk uji hedonik menunjukkan bahwa perlakuan memberikan pengaruh nyata terhadap parameter aroma, warna, tekstur, dan rasa, tetapi tidak berpengaruh nyata terhadap parameter pori dan keseluruhan. Berdasarkan analisis Multiple Attribute Zeleny, perlakuan terbaik didapatkan pada perlakuan teknik pembuatan chiffon cake dan penambahan lemak minyak goreng dengan kadar air $19.87 \%$, kadar karbohidrat $66.03 \%$, kadar protein $3.28 \%$, kadar lemak $9.63 \%$, dan kadar abu $1.2 \%$.
\end{abstract}

Kata kunci: Cake, Lemak, Pasta Ubi Kayu, Telur

\section{ABSTRACT}

In order to develop the use of local raw materials for substitute wheat flour, cassava wa developed for cake production. This research used randomized block design method which was arranged factorially with two factor, which are cake making technique factor, i.e. shuffle yolk and egg whites directly (sponge cake) and shuffle yolk and egg whites separately (chiffon cake) and type of fat, i.e. margarine, cooking oil and non fat. The result of variance analysis (ANOVA) showed that cake making technique and type of fat treatment had significant effect on development volume, hardness, and color $\left(L^{*}, a^{*}, b^{*}\right)$ but no significant effect on water content, and pore size. Friedman test results for hedonic test showed that the treatment gave significant effect on the parameters of flavor, color, texture, and taste, but no significant effect on pore and overall parameters. Based on the analysis of Multiple Attribute Zeleny, the best treatment was obtained in treatment of chiffon cake making technique with addition of cooking oil with $19.87 \%$ water content, $66.03 \%$ carbohydrate, $3.28 \%$ protein, $9.63 \%$ fat, and $1.2 \%$ ash.

Keywords: Cake, Fat, Cassava Paste, Egg

\section{PENDAHULUAN}

Indonesia merupakan pengimpor gandum terbesar di dunia mengalahkan Mesir yang merupakan pengimpor terbesar sebelumnya. Menurut United State Departement of 
Agriculture (USDA), impor gandum di Indonesia meningkat dari 8,10 juta ton pada tahun 2016 menjadi 12.5 juta ton pada tahun 2017-2018. Menurut Diah Maulida, Deputi Bidang Kelautan dan Pertanian Kementerian Koordinator Perekonomian (2012), menyatakan bahwa Indonesia belum bisa memenuhi kebutuhan gandum dalam negeri akibat susahnya gandum untuk tumbuh, sehingga Indonesia harus mengimpor gandum. Penggunaan gandum untuk terigu sendiri mengalami kenaikan mengikuti permintaan konsumen. Pada tahun 2016, konsumsi terigu di Indonesia meningkat sebesar 7\% menjadi 5.43 juta ton (Welirang, 2016).

Pada tahun 1999, konsumsi pangan masyarakat terhadap ubi kayu, jagung, dan umbiumbian menurun drastis. Memasuki tahun 2010, pergeseran konsumsi pangan di Indonesia berubah, dimana konsumsi pangan pokok selain beras nyaris hilang, dan digantikan dengan gandum. Banyak masyarakat Indonesia mulai berpaling ke produk makanan berbasis gandum atau terigu, terutama mie dan dan produk bakery. Bakery banyak diminati masyarakat dari berbagai kalangan, sebab sifatnya lebih praktis untuk dikonsumsi sekaligus mampu memberikan kecukupan gizi.

Terigu mengandung komponen gluten. Dalam pembuatan roti, gluten bermanfaat untuk mengikat dan membuat adonan menjadi elastis sehingga mudah dibentuk (Ratnawati, 2003). Tetapi adanya kandungan gluten pada terigu, membuat sebagian orang dapat menderita penyakit seliak (celiac disease) atau menjadi alergi jika mengonsumsi bahan pangan yang mengandung terigu. Asam amino spesifik yang menyebabkan alergi adalah gliadin yang merupakan asam amino penyusun gluten (Lau et al., 2013). Selain itu, gluten juga tidak baik untuk penderita diabetes melitus karena memiliki nilai indeks glikemik yang tinggi, yaitu 70 (Hasan et al., 2011).

Peningkatan kebutuhan terigu untuk produk pangan yang semakin tinggi akan mengancam ketahanan dan kedaulatan pangan nasional. Oleh karena itu, perlu dikembangkan pemanfaatan bahan baku lokal, misalnya ubi kayu. Ubi kayu atau singkong (Manihot esculenta Crantz atau Manihot utilisima) merupakan salah satu sumber karbohidrat lokal Indonesia yang menduduki urutan ketiga terbesar setelah padi dan jagung. Ubi kayu juga merupakan salah satu komoditas penyumbang ekspor terbesar di Indonesia (Kementerian Pertanian, 2015). Tanaman ini merupakan bahan baku yang paling potensial untuk diolah menjadi tepung, dengan kandungan pati sebesar 35\% (Badan Litbang Pertanian, 2011). Berdasarkan data Badan Pusat Statistik, pada tahun 2015 produksi ubi kayu nasional mencapai 21.8 juta ton (Ladamay et al., 2014). Diperlukan cara meningkatkan porsi penggunaan ubi kayu di Indonesia, salah satunya dengan diolah menjadi produk bakery yaitu kue (cake).

Dalam pembuatan cake berbahan dasar pasta ubi kayu diperlukan formulasi bahan baku serta metode pengolahan yang sesuai. Telur dan lemak merupakan bahan baku penting dalam pembuatan cake. Fungsi telur pada pembuatan cake adalah untuk menambah volume pengembangan, memberi warna, memberi kelembapan, dan memberi tekstur yang lebih lembut (Winarno, 1993). Putih telur dan kuning telur memiliki fungsi yang berbeda pada cake sehingga dapat dilihat perbedaan antara teknik pembuatan cake, yaitu mengocok putih dan kuning telur secara terpisah (chiffon cake) dan mengocok putih dan kuning telur bersamaan (sponge cake). Lemak juga merupakan bahan penting dalam pembuatan cake karena mempengaruhi warna, tekstur dan kelembutan cake. Margarin dan minyak goreng memiliki struktur dan karakteristik yang berbeda sehingga mempengaruhi cake yang dihasilkan. Berdasarkan uraian di atas, kedua faktor yang akan dikaji dalam penelitian ini adalah teknik pembuatan cake dan jenis lemak yang digunakan. Dari kedua faktor tersebut dapat dilihat perbedaannya dan dapat menentukan perlakuan terbaik dengan uji fisikomia dan organoleptik sehingga dihasilkan cake dari pasta ubi kayu yang bisa layak dikonsumsi.

\section{BAHAN DAN METODE}

Alat

Alat yang digunakan dalam penelitian ini adalah kompor gas, panci pengukus, oven listrik (merk Kirin), mixer (Phillips), meat grinder (Geepas MG-380), timbangan analitik, baskom, loyang, pisau, sendok, solet, plastik, kertas roti. Alat yang digunakan untuk analisis adalah Colour Reader (Konica Minolta), Tensile Strength (Imada ZR-200N), kompor listrik (maspion), 
spektrofotometer dan kuvet (UNICO RRC UV 2100), oven listrik (WTB Binder), desikator (Scoot Duran), Soxhlet (Behr), vortex (Turbo Mixer), vacuum pump (Rocker), distilator dan destruktor (Buchi), neraca analitik, lemari asam, pendingin balik, bola hisap, kertas saring, statip, rak tabung, dan glassware.

\section{Bahan}

Bahan yang digunakan dalam penelitian ini adalah ubi kayu yang didapatkan di pasar Belimbing, Malang, Jawa Timur, susu bubuk full cream (Indomilk), margarin (Blue Band), minyak goreng (Sunco), telur, gula pasir (Gulaku), dan baking powder. Bahan yang digunakan untuk analisis adalah petroleum eter, tablet Kjeldahl, Alkohol $10 \%, \mathrm{HCl} 25 \%, \mathrm{NaOH} 45 \%, \mathrm{HCl}$ $0,1 \mathrm{~N}, \mathrm{NaOH} 30 \%, \mathrm{H}_{2} \mathrm{SO}_{4}$ pekat, $\mathrm{H}_{3} \mathrm{BO}_{3} 4 \%$, larutan asam borat 3\%, Reagen Nelson $\mathrm{A}$ dan Nelson B, arseno molibdat, petroleum eter, indikator methyl red, indikator PP dan aquades.

\section{Desain Penelitian}

Penelitian ini menggunakan Rancangan Acak Kelompok yang disusun secara faktorial dengan menggunakan dua faktor. Faktor I adalah teknik pembuatan cake, yaitu pengocokan kuning dan putih telur secara langsung dan bersamaan (sponge cake) dan pengocokan kuning dan putih di wadah terpisah (chiffon cake). Faktor II adalah jenis lemak, yaitu tanpa penambahan lemak, margarin, dan minyak goreng. Data dianalisis dengan menggunakan metode ANOVA dan dilanjutkan dengan uji lanjut Metode Bonferroni menggunakan aplikasi Minitab. Data hasil uji organoleptik dianalisis menggunakan uji Hedonic. Sedangkan pemilihan perlakuan terbaik menggunakan metode Multiple Attribute berdasarkan parameter fisik dan organoleptik dan dilanjutkan uji T untuk membandingkan cake perlakuan terbaik dengan cake kontrol.

\section{Tahapan Penelitian}

\section{Persiapan Alat dan Bahan}

Seluruh alat yang akan digunakan disiapkan yaitu mixer, sendok, garpu, pisau, solet, baskom, oven dan timbangan Bahan yang dibutuhkan ditimbang masing-masing yaitu telur ( 2 butir/100 gram), margarin (20 gram), minyak goreng (20 gram), air (20 gram), gula pasir (40 gram), susu bubuk (25 gram), dan baking powder (1 gram).

\section{Pembuatan Pasta Ubi Kayu}

Ubi kayu dikupas seluruh kulitnya kemudian dipotong dan dicuci bersih. Siapkan air dalam panci pengukus lalu dipanaskan hingga mendidih $\left(100^{\circ} \mathrm{C}\right)$, kemudian ubi kayu yang telah dipotong dan dicuci dimasukkan ke dalam panci untuk dikukus hingga empuk ( \pm 45 menit) setelah itu ditiriskan. Ubi kayu yang telah ditiriskan dihaluskan, setelah itu dimasukkan ke dalam plastik lalu disimpan di dalam freezer selama 48 jam. Setelah satu hari, pasta dikeluarkan dan dihaluskan dengan grinder kemudian disimpan selama 24 jam di lemari pendingin. Saat akan digunakan, pasta ditimbang sebanyak 120 gram dengan menggunakan timbangan.

\section{Pembuatan Sponge Cake Ubi Kayu}

Telur dan gula pasir dimasukkan ke dalam baskom lalu dimixer dengan kecepatan rendah hingga tinggi hingga berwarna putih pucat. Kemudian dimasukkan pasta ubi kayu dan susu bubuk secara perlahan, selanjutnya ditambahkan lemak dan diaduk perlahan menggunakan solet dan terakhir ditambahkan baking powder dan diaduk secara cepat. Setelah itu adonan langsung dimasukkan dalam loyang yang sudah dilapisi kertas roti dan di oven menggunakan oven listrik dengan suhu $170^{\circ} \mathrm{C}$ selama 40 menit.

\section{Pembuatan Chiffon Cake Ubi Kayu}

Telur dipisahkan putih dan kuningnya. Bagian putih telur dikocok dari kecepatan rendah ke kecepatan tinggi, gula pasir dimasukkan sedikit demi sedikit. Pengocokan dilakukan hingga putih telur mengembang, putih, dan halus/lembut. Kemudian dimasukkan ke dalam kuning 
telur yang sudah dikocok dan diaduk perlahan menggunakan solet. Setelah itu bahan-bahan lain seperti susu bubuk, pasta ubi kayu, lemak dan baking powder dimasukan satu persatu dan diaduk hingga rata. Setelah itu adonan dimasukkan dalam loyang yang sudah dilapisi kertas roti dan di oven menggunakan oven listrik dengan suhu $170^{\circ} \mathrm{C}$ selama 40 menit.

\section{Analisis Penelitian}

Analisis fisik cake meliputi volume pengembangan, kekerasan, ukuran pori, dan warna. Analisis kimia cake meliputi kadar air. Analisis organoleptik cake menggunakan uji kesukaan (hedonik). Analisis kimia cake perlakuan terbaik meliputi kadar protein, kadar lemak, kadar air, dan kadar abu.

\section{HASIL DAN PEMBAHASAN}

\section{Karakteristik Bahan Baku}

Pasta ubi kayu yang digunakan sebagai bahan baku dianalisis karakteristik kimia-nya berupa kadar air, lemak, protein, abu, dan karbohidrat.

Tabel 1. Data Analisis Kimia Bahan Baku Pasta Ubi Kayu dibandingkan dengan Literatur

\begin{tabular}{lrc}
\hline Parameter (\%) & Pasta Ubi Kayu & Ubi Kayu Segar \\
\hline Air & 64.54 & 62.50 \\
Karbohidrat & 33.44 & 34.70 \\
Protein & 1.03 & 1.20 \\
Lemak & 0.29 & 0.30 \\
Abu & 0.71 & 1.30 \\
\hline
\end{tabular}

Keterangan: *Hasil analisis penelitian

**Literatur: Depkes RI (1981)

Tabel 1. menunjukkan perbedaan kandungan antara pasta ubi kayu dan ubi kayu segar. Pasta ubi kayu diproses dengan menggunakan perebusan dan pembekuan sehingga menghasilkan sedikit perbedaan kandungan kimianya. Proses perebusan ubi kayu menyebabkan kadar air pada pasta ubi kayu meningkat drastis, namun akibat proses pembekuan, air akan mengalami dehidrasi sehingga kadar air tidak jauh berbeda (Apriantono et al., 1989).

Ubi kayu segar memiliki struktur yang keras, sehingga apabila digunakan langsung untuk membuat cake akan menghasilkan cake yang liat untuk dimakan. Oleh karena itu, dengan dibentuk menjadi pasta akan merubah strukturnya yang keras menjadi lebih lunak dikarenakan adanya gelatinisasi pati. Gelatinisasi pati terjadi dengan adanya penambahan sejumlah air pada pati dan dipanaskan pada suhu tinggi, kemudian granula patinya akan menyerap air dan membengkak (Ginting, 2014). Komponen penyusun struktur pati tergelatinisasi adalah molekul amilopektin.

Terjadinya gelatinisasi pati ini bermula ketika pati direndam dalam air panas. Air akan berpenetrasi masuk ke dalam granula pati secara perlahan dan bolak-balik, sehingga menyebabkan rusaknya ikatan double helix pada amilopektin dan putusnya ikatan hidrogen antar molekul dalam granula. Putusnya ikatan akan membuat struktur dari pati terbuka dan diharapkan akan semakin lebih mudah untuk berinteraksi dengan molekul lain saat proses pencampuran adonan cake nantinya (Imanningsih, 2012).

\section{Karakteristik Fisik}

Volume Pengembangan

Tabel 2 menunjukkan bahwa teknik pembuatan cake dan jenis lemak memberikan pengaruh nyata terhadap volume pengembangan cake ubi kayu. Sponge cake memiliki volume pengembangan yang lebih rendah dibandingkan dengan chiffon cake. Hal ini disebabkan karena pada teknik pembuatan chiffon cake terbentuk busa/buih yang berpengaruh pada pengembangan volume. Protein yang berpengaruh dalam pembentukan 
busa adalah ovalbumin (protein terbesar yang menyusun putih telur, yang terdiri dari empat gugus - SH) dan globulin (protein yang tidak larut air tetapi larut dalam garam). Pembentukan busa diawali dengan terbukanya ikatan dalam molekul protein, sehingga rantai protein menjadi lebih panjang. Kemudian udara masuk diantara molekul protein yang terbuka dan bertahan sehingga volumenya mengembang. Jika pada kondisi volume mengembang, busa yang terbentuk dipanasi maka akan terjadi denaturasi protein, sehingga busa yang terbentuk menjadi lebih stabil dan terjadi pengembangan adonan (Suhardi, 1988). Pada sponge cake, karena kuning dan putih telur dikocok bersama, maka pengembangan busa tidak akan maksimal karena kuning telur mengandung lemak. Lemak akan menganggu pembentukan busa dan menurunkan volume busa. Lapisan dibentuk oleh lemak umumnya tidak kuat dan tidak elastis, sehingga gelembung udara yang terbentuk mudah pecah (Romanof and Romanoff, 1993).

Tabel 2. Data Hasil Analisis Volume Pengembangan Cake Ubi Kayu berdasarkan Perlakuan Teknik Pembuatan Cake dan Jenis Lemak

\begin{tabular}{ccc}
\hline Perlakuan & Volume Pengembangan $(\%)$ & $\mathrm{p}$ - value \\
\hline Sponge Cake & $13.96 \pm 1.81 \mathrm{~b}$ & 0.002 \\
Chiffon Cake & $16.60 \pm 2.23 \mathrm{a}$ & \\
\hline Tanpa Lemak & $13.18 \pm 1.65 \mathrm{~b}$ & \\
Margarin & $15.81 \pm 1.56 \mathrm{a}$ & 0.002 \\
Minyak Goreng & $16.84 \pm 2.41 \mathrm{a}$ & \\
\hline
\end{tabular}

Keterangan : Setiap data merupakan rerata dari 3 ulangan

Walaupun secara keseluruhan berbeda nyata, namun volume pengembangan antara cake dengan penambahan jenis lemak margarin dan minyak goreng tidak berbeda nyata. Hal ini disebabkan karena sifat plastis dari margarin yang memegang peranan penting dimana apabila lemak plastis dicampur dengan adonan, maka adonan tersebut dapat membentuk sejenis film. Adonan berlemak ini mempunya daya gabung dengan udara dan daya pelumas lebih besar dibandingkan dengan minyak cair. Selain itu, perbandingan antara jumlah penambahan lemak dan gula dalam adonan mempengaruhi jumlah volume udara yang dapat diserap oleh lemak. Perbandingan berat optimum antara gula dan lemak yang ditambahkan sebesar 3:2 akan menghasilkan daya gabung udara dengan lemak yang maksimal. Makin halus partikel gula dan makin lama pencampuran, maka jumlah udara yang terserap semakin besar (Winarno, 2002). Minyak goreng memiliki kandungan asam lemak tidak jenuh pada yang tinggi. Semakin tinggi kandungan asam lemak tidak jenuh, daya gabung udara dengan lemak semakin besar (Ketaren et al., 1985). Volume pengembangan juga erat hubungannya dengan kadar air. Semakin tinggi nilai kadar air, maka nilai volume pengembangan semakin tinggi pula. Hal ini terjadi karena daya serap air pada tepung terigu yang tinggi dibandingkan pati atau tepung lainnya, dimana protein gluten pada tepung terigu memiliki daya serap yang tinggi dikarenakan gluten membutuhkan air lebih banyak untuk dapat menyimpan gas sebanyak-banyaknya (Adeleke dan Odedeji, 2010).

Kekerasan

Tabel 3. Data Hasil Analisis Kekerasan Cake Ubi Kayu berdasarkan Perlakuan Teknik Pembuatan Cake dan Jenis Lemak

\begin{tabular}{ccc}
\hline Perlakuan & Kekerasan $(\mathrm{N})$ & $\mathrm{p}$ - value \\
\hline Sponge Cake & $6.40 \pm 1.80 \mathrm{~b}$ & 0.005 \\
Chiffon Cake & $7.81 \pm 1.93 \mathrm{a}$ & \\
\hline Tanpa Lemak & $8.78 \pm 1.02 \mathrm{a}$ & \\
Margarin & $7.63 \pm 1.27 \mathrm{a}$ & 0.000 \\
Minyak Goreng & $4.90 \pm 0.86 \mathrm{~b}$ & \\
\hline
\end{tabular}

Keterangan : Setiap data merupakan rerata dari 3 ulangan 
Dari Tabel 3 menunjukkan bahwa perlakuan teknik pembuatan cake dan jenis lemak yang berbeda memberikan pengaruh nyata terhadap kekerasan cake ubi kayu.

Sponge cake memiliki tekstur yang agak kasar, kurang lentur dan cenderung beremah apabila dipotong (Rumini, 2010). Sedangkan chiffon cake memiliki tekstur yang lembut (Issutarti, 2006). Nilai kekerasan berhubungan erat dengan volume pengembangan. Semakin tinggi volume pengembangan, maka nilai kekerasan akan semakin rendah (Sudaryati, 2013). Namun dalam penelitian ini, tekstur yang dihasilkan chiffon cake lebih keras dibandingkan dengan tekstur dari sponge cake. Ketidaksesuaian ini mungkin disebabkan karena saat proses pembakaran, granula pati akan membengkak dan lemak atau shortening akan menekan pembengkakan pati ini. Selanjutnya, molekul pati yang membengkak akan berinteraksi dengan lemak atau shortening sehingga ikatan silang pati dan protein menjadi lemah. Hal ini yang mengakibatkan kekerasan roti menjadi berkurang (Mudjisihono, 2003).

Gluten pada tepung terigu akan membuat tekstur cake tidak keras. Hal ini dikarenakan kemampuan gluten untuk memerangkap air, sehingga saat pemanggangan, proses penguapan air dapat dicegah atau tidak banyak (Wang et al., 2006). Dari hasil penelitian, cake tanpa menggunakan lemak atau dengan subtitusi air memiliki nilai tertinggi atau merupakan cake yang paling keras teksturnya. Hal ini disebabkan karena penggunaan bahan baku pasta ubi kayu yang mengandung pati. Air pada proses pemanggangan akan menguap lebih banyak dikarenakan tidak adanya gluten yang dapat mengikat air lebih banyak sehingga cake yang dihasilkan menjadi lebih keras setelah didinginkan (Murdani, 2010). Selain itu, cake tanpa penambahan lemak memiliki tekstur yang lebih keras dibandingkan dengan cake yang diberi penambahan lemak karena lemak akan membantu mengempukkan produk. Cake dengan penambahan minyak goreng memiliki tekstur yang paling empuk atau lembut dikarenakan udara yang terperangkap dalam adonan tercampur bagus. Menurut Ketaren dan Djatmiko (1985), semakin banyak kandungan asam lemak tidak jenuh, daya gabung udara semakin dalam adonan akan semakin baik. Minyak goreng memiliki kandungan asam lemak tidak jenuh yang lebih tinggi dibandingkan dengan margarin. Pada margarin, asam lemak tidak jenuh telah diubah menjadi asam lemak jenuh pada proses hidrogenasi. Selain itu, margarin yang mengandung asam lemak jenuh yang tinggi akan menyebabkan pembentukan matriks protein menjadi rapat sehingga tekstur cake yang dihasilkan menjadi lebih keras.

\section{Ukuran Pori}

Pengukuran pori menggunakan hasil scan dari cake ubi kayu yang telah dipotong menjadi ukuran 3 × $3 \mathrm{~cm}$ kemudian dianalisis menggunakan software Image $\mathrm{J}$.

Tabel 4. Data Hasil Analisis Ukuran Pori Cake Ubi Kayu berdasarkan Perlakuan Teknik Pembuatan Cake dan Jenis Lemak

\begin{tabular}{ccc}
\hline Perlakuan & Ukuran Pori $\left(\mathrm{mm}^{2}\right)$ & $\mathrm{p}$ - value \\
\hline Sponge Cake & $0.363 \pm 0.132$ & 0.599 \\
Chiffon Cake & $0.336 \pm 0.113$ & \\
\hline Tanpa Lemak & $0.333 \pm 0.133$ & \\
Margarin & $0.311 \pm 0.051$ & 0.325 \\
Minyak Goreng & $0.404 \pm 0.152$ & \\
\hline
\end{tabular}

Keterangan : Setiap data merupakan rerata dari 3 ulangan

Dari Tabel 4 menunjukkan bahwa perlakuan teknik pembuatan cake dan jenis lemak yang berbeda tidak memberikan pengaruh nyata terhadap ukuran pori cake ubi kayu. Pori merupakan lubang-lubang kecil yang terbentuk karena adanya gas $\mathrm{CO}_{2}$ yang terperangkap dalam adonan saat dipanggang. Pori sangat dipengaruhi oleh kemampuan pembentukan gas dan penahanan gas selama proses pengovenan (Mudjisihono et al., 2000). Pori juga sangat dipengaruhi oleh udara yang terperangkap dalam adonan. Apabila udara yang terperangkap dalam adonan sangat bagus, maka pori yang dihasilkan sangat halus dan jumlahnya sangat banyak. Penambahan lemak yang tidak tepat akan mengakibatkan udara tidak dapat 
bercampur dengan baik dalam adonan sehingga memberikan ukuran pori yang besar, sehingga tampak kasar. Menurut Ketaren dan Djatmiko (1985), semakin banyak kandungan asam lemak tidak jenuh, maka daya gabung udara semakin baik. Volume pengembangan juga erat hubungannya dengan rata-rata diameter atau ukuran pori. Semakin tinggi nilai volume pengembangan, maka nilai rata-rata diameter atau ukuran pori juga akan semakin meningkat. Banyaknya gas $\mathrm{CO}_{2}$ yang terperangkap dalam struktur adonan menyebabkan diameter atau ukuran pori menjadi semakin besar (Czernohorsky dan Hooker, 2008).

\section{Warna}

Nilai Kecerahan $\left(L^{*}\right)$

Tabel 5. Data Hasil Analisis Nilai Kecerahan Cake Ubi Kayu bagian Crust berdasarkan Perlakuan Teknik Pembuatan Cake dan Jenis Lemak

\begin{tabular}{ccc}
\hline Perlakuan & Nilai Kecerahan $\left(\mathrm{L}^{*}\right)$ & $\mathrm{p}$ - value \\
\hline Sponge Cake & $56.14 \pm 3.60$ & 0.091 \\
Chiffon Cake & $53.11 \pm 5.62$ & \\
\hline Tanpa Lemak & $56.25 \pm 4.16$ & \\
Margarin & $54.35 \pm 4.41$ & 0.356 \\
Minyak Goreng & $53.28 \pm 6.11$ & \\
\hline
\end{tabular}

Keterangan : Setiap data merupakan rerata dari 3 ulangan

Pada Tabel 5 menunjukkan bahwa perlakuan teknik pembuatan cake dan jenis lemak yang berbeda tidak memberikan pengaruh nyata terhadap nilai kecerahan cake ubi kayu bagian luar (crust). Pada proses pemanggangan cake, terjadi perubahan baik pada kulit maupun remah cake, yaitu terjadi reaksi pencoklatan akibat peristiwa karamelisasi dan terbentuknya ikatan gula dan protein atau disebut dengan reaksi maillard. Selain itu juga terjadi dekomposisi pati oleh panas dan pembentukan dekstrin (Pomeranz dan Shellenberger, 2001).

Tabel 6. Data Hasil Analisis Nilai Kecerahan Cake Ubi Kayu bagian Crumb berdasarkan Perlakuan Teknik Pembuatan Cake dan Jenis Lemak

\begin{tabular}{ccc}
\hline Perlakuan & Nilai Kecerahan $\left(\mathrm{L}^{*}\right)$ & $\mathrm{p}$ - value \\
\hline Sponge Cake & $68.31 \pm 1.28$ & 0.034 \\
Chiffon Cake & $70.00 \pm 2.29$ & \\
\hline Tanpa Lemak & $69.83 \pm 2.53$ & \\
Margarin & $68.40 \pm 1.86$ & 0.278 \\
Minyak Goreng & $69.23 \pm 1.57$ & \\
\hline
\end{tabular}

Keterangan : Setiap data merupakan rerata dari 3 ulangan

Dari Tabel 6 menunjukkan bahwa perlakuan teknik pembuatan cake yang berbeda memberikan pengaruh nyata terhadap nilai kecerahan cake ubi kayu bagian dalam (crumb) sedangkan jenis lemak yang berbeda tidak memberikan pengaruh nyata terhadap nilai kecerahan cake ubi kayu bagian crumb. Teknik pembuatan chiffon cake memiliki nilai kecerahan lebih tinggi dibandingkan dengan sponge cake. Hal ini disebabkan karena adanya perbedaan pengocokan telur dimana pada chiffon cake, putih telur dan kuning telur dikocok secara terpisah. Putih telur yang mengembang membentuk busa dan memberikan warna putih pucat sehingga warna crumb yang dihasilkan akan lebih cerah dibandingkan dengan sponge cake. Sponge cake pada prosesnya langsung mengocok telur utuh sehingga warna adonan yang dihasilkan sangat kuning dan akan berpengaruh pada hasil cake setelah dipanggang (Suhardjito, 2003).

Nilai Kemerahan $\left(a^{*}\right)$

Tabel 7. Data Hasil Analisis Nilai Kemerahan Cake Ubi Kayu bagian Crust berdasarkan Perlakuan Teknik Pembuatan Cake dan Jenis Lemak

$\begin{array}{ccc}\text { Perlakuan } & \text { Nilai Kemerahan }\left(\mathrm{a}^{*}\right) & \mathrm{p} \text { - value } \\ \text { Sponge Cake } & 11.51 \pm 2.25 & 0.197\end{array}$




\begin{tabular}{ccc}
\hline Chiffon Cake & $12.78 \pm 1.39$ & \\
\hline Tanpa Lemak & $11.87 \pm 1.75$ & \\
Margarin & $11.88 \pm 1.73$ & 0.715 \\
Minyak Goreng & $12.68 \pm 2.46$ &
\end{tabular}

Keterangan : Setiap data merupakan rerata dari 3 ulangan

Dari Tabel 7 menunjukkan bahwa perlakuan teknik pembuatan cake dan jenis lemak yang berbeda tidak memberikan pengaruh nyata terhadap nilai kemerahan cake ubi kayu bagian luar (crust). Pada proses pemanggangan cake, terjadi perubahan baik pada kulit maupun remah cake, yaitu terjadi reaksi pencoklatan akibat peristiwa karamelisasi dan terbentuknya ikatan gula dan protein atau disebut dengan reaksi maillard. Selain itu juga terjadi dekomposisi pati oleh panas dan pembentukan dekstrin (Pomeranz dan Shellenberger, 2001).

Tabel 8. Data Hasil Analisis Nilai Kemerahan Cake Ubi Kayu bagian Crumb berdasarkan Perlakuan Teknik Pembuatan Cake dan Jenis Lemak

\begin{tabular}{ccc}
\hline Perlakuan & Nilai Kemerahan $\left(\mathrm{a}^{*}\right)$ & $\mathrm{p}$ - value \\
\hline Sponge Cake & $-0.82 \pm 0.65$ & 0.898 \\
Chiffon Cake & $-0.78 \pm 1.09$ & \\
\hline Tanpa Lemak & $-1.33 \pm 0.16 \mathrm{~b}$ & \\
Margarin & $0.07 \pm 0.95 \mathrm{a}$ & 0.014 \\
Minyak Goreng & $-1.13 \pm 0.50 \mathrm{~b}$ & \\
\hline
\end{tabular}

Keterangan : Setiap data merupakan rerata dari 3 ulangan

Pada Tabel 8 menunjukkan bahwa perlakuan teknik pembuatan cake yang berbeda tidak memberikan pengaruh nyata terhadap nilai kemerahan cake ubi kayu bagian dalam (crumb) sedangkan perlakuan jenis lemak yang berbeda memberikan pengaruh nyata terhadap nilai kemerahan cake ubi kayu bagian dalam (crumb).

Margarin memiliki nilai kemerahan yang paling tinggi, hal ini disebabkan karena dalam proses pembuatannya, ditambahkan karoten untuk mendapatkan produk dengan yang bagus. Cake dengan menggunakan minyak goreng hanya mengandung sedikit karoten, sedangkan cake tanpa penambahan lemak menghasilkan cake dengan warna kuning pucat dikarenakan hanya ditambahkan oleh air sebagai subtitusi dari lemak (Issurtati, 2006).

Nilai Kekuningan $\left(b^{*}\right)$

Tabel 9. Data Hasil Analisis Nilai Kekuningan Cake Ubi Kayu bagian Crust berdasarkan Perlakuan Teknik Pembuatan Cake dan Jenis Lemak

\begin{tabular}{ccc}
\hline Perlakuan & Nilai Kekuningan $\left(\mathrm{b}^{\star}\right)$ & $\mathrm{p}$ - value \\
\hline Sponge Cake & $29.66 \pm 5.10 \mathrm{a}$ & 0.004 \\
Chiffon Cake & $24.78 \pm 5.15 \mathrm{~b}$ & \\
Tanpa Lemak & $27.90 \pm 4.40$ & \\
Margarin & $25.18 \pm 5.49$ & 0.139 \\
Minyak Goreng & $28.57 \pm 6.95$ & \\
\hline
\end{tabular}

Keterangan : Setiap data merupakan rerata dari 3 ulangan

Dari Tabel 9 menunjukkan bahwa perlakuan teknik pembuatan cake yang berbeda memberikan pengaruh nyata terhadap nilai kekuningan cake ubi kayu bagian luar (crust) sedangkan perlakuan jenis lemak yang berbeda tidak memberikan pengaruh nyata terhadap nilai kekuningan cake ubi kayu bagian luar (crust).

Pada sponge cake, warna adonan yang dihasilkan jauh lebih kuning dibandingkan dengan chiffon cake. Busa berwarna putih yang dihasilkan pada teknik pembuatan chiffon cake akan menyebabkan warna adonan lebih cerah dibandingkan dengan sponge cake sehingga akan berpengaruh terhadap crust yang dihasilkan. Warna kuning yang dominan dari adonan berasal dari kuning telur. Kuning telur mengandung beberapa pigmen antara lain xantofil, lutein, beta karoten, dan kriptoxantin (Rumini, 2010). 
Tabel 10. Data Hasil Analisis Nilai Kekuningan Cake Ubi Kayu bagian Crumb berdasarkan

Perlakuan Teknik Pembuatan Cake dan Jenis Lemak

\begin{tabular}{ccc}
\hline Perlakuan & Nilai Kekuningan $\left(\mathrm{b}^{\star}\right)$ & $\mathrm{p}$ - value \\
\hline Sponge Cake & $33.44 \pm 1.98$ & 0.431 \\
Chiffon Cake & $34.09 \pm 1.59$ & \\
\hline Tanpa Lemak & $32.98 \pm 1.69$ & \\
Margarin & $34.78 \pm 1.90$ & 0.209 \\
Minyak Goreng & $33.53 \pm 1.49$ & \\
\hline
\end{tabular}

Keterangan : Setiap data merupakan rerata dari 3 ulangan

Dari Tabel 10 menunjukkan bahwa perlakuan teknik pembuatan cake dan jenis lemak yang berbeda tidak memberikan pengaruh nyata terhadap nilai kekuningan cake ubi kayu bagian dalam (crumb). Hal ini disebabkan karena warna penggunaan lemak dalam jumlah yang sedikit, yaitu hanya $6.4 \%$ dari total adonan sehingga warna kuning yang dihasilkan tidak jauh berbeda.

\section{Kadar Air}

Tabel 11. Data Hasil Analisis Kadar Air Cake Ubi Kayu berdasarkan Perlakuan Teknik Pembuatan Cake dan Jenis Lemak

\begin{tabular}{ccc}
\hline Perlakuan & Kadar Air (\%) & p-value \\
\hline Sponge Cake & $20.15 \pm 3.14$ & 0.591 \\
Chiffon Cake & $19.49 \pm 1.42$ & \\
\hline Tanpa Lemak & $18.45 \pm 2.62$ & \\
Margarin & $20.22 \pm 1.33$ & 0.293 \\
Minyak Goreng & $20.78 \pm 2.69$ & \\
\hline
\end{tabular}

Keterangan : Setiap data merupakan rerata dari 3 ulangan

Dari Tabel 11 menunjukkan bahwa perlakuan teknik pembuatan cake dan jenis lemak yang berbeda tidak memberikan pengaruh nyata terhadap kadar air cake ubi kayu. Menurut USDA (2016), cake memiliki kadar air yang cukup tinggi, yaitu sekitar $29.40 \%$. Namun pada hasil penelitian menunjukkan kadar air jauh lebih rendah. Hal ini disebabkan karena adanya perbedaan bahan baku yang digunakan. Tepung terigu mengandung protein yang akan membentuk adonan yang kuat dengan penambahan air dan garam yang dinamakan dengan protein gluten (deMan, 1999). Gluten pada tepung terigu dapat mengikat air jauh lebih kuat dibandingkan dengan pati atau tepung-tepungan lainnya. Bahan baku yang digunakan dalam penelitian ini merupakan pasta ubi kayu, dimana ubi kayu terdiri dari $83 \%$ amilopektin. Amilopektin bersifat sukar menyerap air dan sukar melepas air (Harzau et al., 2013). Hal ini menyebabkan air pada adonan akan menguap lebih banyak pada proses pemanggangan dan mengakibatkan kadar air pada cake jauh lebih rendah.

\section{Uji Hedonik}

Pada uji ini, 31 panelis tidak terlatih diminta memberikan tanggapan dan penilaian terhadap produk cake dengan memberikan skor tingkat kesukaan. Tingkat kesukaan disebut juga skala hedonik dengan skala (1-5) dari sangat tidak menyukai sampai sangat menyukai terhadap parameter rasa, aroma, warna, tekstur dan keseluruhan cake ubi kayu.

Gambar 1 menunjukkan bahwa berdasarkan parameter warna, cake dengan menggunakan teknik chiffon cake dan penambahan minyak goreng yang paling disukai. Berdasarkan parameter aroma, cake dengan menggunakan teknik chiffon cake dan penambahan margarin yang paling disukai. Berdasarkan parameter pori, cake dengan menggunakan teknik chiffon cake dengan penambahan margarin dan sponge cake dengan penambahan minyak goreng yang paling disukai. Berdasarkan parameter tekstur, cake dengan menggunakan teknik chiffon cake umumnya lebih disukai dibandingkan dengan sponge cake. Berdasarkan parameter rasa, cake dengan menggunakan teknik sponge cake dan penambahan margarin yang paling disukai. Secara keseluruhan, cake dengan 
mengggunakan teknik chiffon cake dan penambahan minyak goreng merupakan produk cake yang paling disukai panelis. Hal ini disebabkan karena pada dasarnya, lemak yang digunakan pada proses pembuatan chiffon cake adalah minyak nabati. Chiffon cake sendiri memiliki tekstur yang lembut dan pengembangan yang bagus walau rasanya sedikit hambar karena penggunaan minyak (Issutarti, 2006).

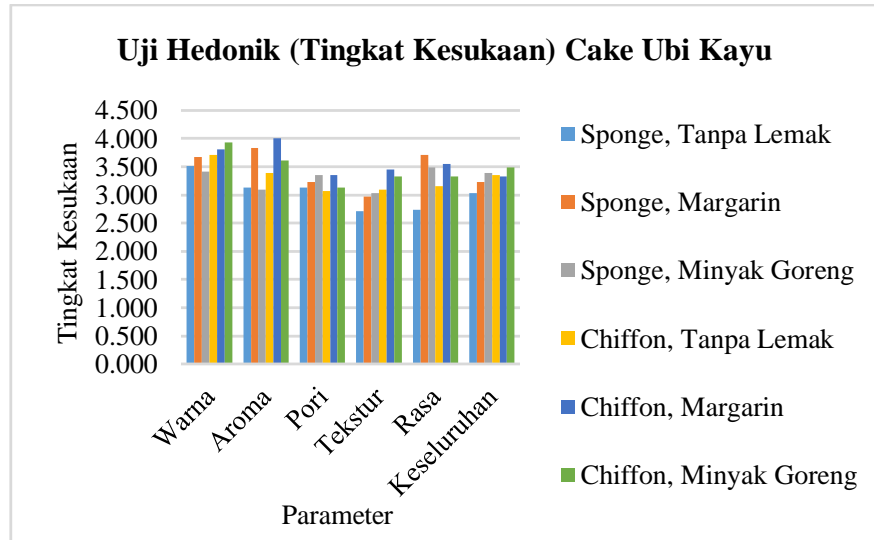

Gambar 1. Grafik Tingkat Kesukaan Panelis terhadap Cake Ubi Kayu

\section{Penentuan Perlakuan Terbaik}

Pemilihan perlakuan terbaik pada penelitian ini ditentukan dengan metode multiple attributes (Zeleny). Dari hasil uji, didapatkan perlakuan terbaik yaitu teknik pembuatan chiffon cake dengan penambahan jenis lemak minyak goreng. Cake perlakuan terbaik dibandingkan dengan cake kontrol.

Tabel 22. Perbandingan Parameter Fisik dan Kimia Cake Perlakuan Terbaik dengan Cake Kontrol

\begin{tabular}{lcc}
\hline \multicolumn{1}{c}{ Parameter Fisik } & $\begin{array}{c}\text { Cake Ubi Kayu Perlakuan } \\
\text { Terbaik }\end{array}$ & Cake Kontrol \\
\hline Warna Kecerahan Crust $\left(\mathrm{L}^{*}\right)$ & $49.90 \pm 6.81$ & 52.7 \\
Warna Kecerahan Crumb $\left(\mathrm{L}^{*}\right)$ & $69.43 \pm 1.70$ & 77.2 \\
Warna Kemerahan Crust $\left(\mathrm{a}^{*}\right)$ & $13.37 \pm 1.46$ & 12.8 \\
Warna Kemerahan Crumb $\left(\mathrm{a}^{*}\right)$ & $-1.10 \pm 0.72$ & -0.6 \\
Warna Kekuningan Crust $\left(\mathrm{b}^{*}\right)$ & $23.87 \pm 6.73$ & 24.1 \\
Warna Kekuningan Crumb $\left(\mathrm{b}^{*}\right)$ & $34.73 \pm 0.15$ & 32.5 \\
Kekerasan (Hardness) $(\mathrm{N})$ & $5.50 \pm 0.79$ & 15.5 \\
Volume Pengembangan $(\%)$ & $18.77 \pm 0.98$ & 19.35 \\
Ukuran Pori (mm $\left.{ }^{2}\right)$ & $0.438 \pm 0.132$ & 0.297 \\
\hline \multicolumn{1}{c}{ Parameter Kimia } & Cake Ubi Kayu Perlakuan & Cake Kontrol \\
& Terbaik & \\
\hline Kadar Air (\%bb) & $19.87 \pm 2.05$ & $23.48 \pm 1.6$ \\
Kadar Lemak (\%bb) & $3.28 \pm 0.55$ & $3.72 \pm 0.21$ \\
Kadar Protein (\%bb) & $9.63 \pm 0.71$ & $12.71 \pm 0.83$ \\
Kadar Abu (\%bb) & $1.2 \pm 0.24$ & $0.78 \pm 0.1$ \\
Kadar Karbohidrat (\%bb) & 66.03 & 59.32 \\
\hline
\end{tabular}

Dari hasil pengamatan, selanjutnya dicari perbedaan rata-rata dari cake ubi kayu perlakuan terbaik dan cake kontrol dengan menggunakan uji T (independent simple $T$ test). Hasil dari uji T ini menunjukkan nilai signifikansi sebesar 0.876 lebih besar dibandingkan tingkat signifikansi ( $\alpha=5 \%$ atau 0.05 ) sehingga dapat disimpulkan bahwa secara statistik kedua kelompok cake memiliki rata-rata parameter yang hampir sama. 
Adanya perbedaan kandungan kimia dari kedua cake disebabkan karena adanya perbedaan bahan baku yang digunakan. Cake kontrol menggunakan bahan baku tepung terigu yang mengandung gluten. Gluten merupakan protein yang menggumpal yang memiliki zat elastis sehingga mampu menyerap gas $\mathrm{CO}_{2}$ ketika dilakukan pengocokan. Peningkatan tekanan udara ini akan memperbesar dinding sel, sehingga produk akan mengembang (Choi et al., 2012).

\section{SIMPULAN}

Dari hasil penelitian, perbedaan teknik pembuatan cake dan jenis lemak memberikan pengaruh nyata terhadap karakterstik organoleptik, kekerasan, volume pengembangan, warna crust dan crumb. Namun, perbedaan teknik pembuatan cake dan jenis lemak tidak memberikan pengaruh nyata pada porositas dan kadar air. Adanya perbedaan pada proses pengocokan telur, yaitu dicampur bersama atau dipisah akan mempengaruhi cake yang dihasilkan. Penambahan lemak berfungsi untuk memberikan kelembapan, memperbaiki cita rasa dan tekstur, membantu dalam aerasi atau pencampuran adonan, memberikan warna pada permukaan, serta menaikkan nilai gizi.

Berdasarkan karakteristik fisik dan organoleptik yang diuji, didapatkan perlakuan terbaik dari hasil perhitungan menggunakan metode Zeleny yaitu perlakuan teknik pembuatan chiffon cake dan jenis lemak minyak goreng (T2L3). Perlakuan terbaik ini memiliki kadar air $19.87 \%$, kadar karbohidrat $66.03 \%$, kadar protein $3.28 \%$, kadar lemak $9.63 \%$, dan kadar abu $1.2 \%$.

\section{DAFTAR PUSTAKA}

Adeleke, R.O., dan Odedeji, J.O. 2010. Functional Properties of Wheat and Sweet Potato Flour Blends. Pakistan Journal of Nutrition 9:6, 535-538.

Apriantono, A. Dan D. Fardiaz. 1989. Analisis Pangan. Departemen Pendidikan dan Kebudayaan, Dirjen Pendidikan Tinggi PAU Pangan dan Gizi IPB. Bogor.

Choi, H. W., T. Harris, and Byung-Kee. 2012. Improvement of Sponge Cake Baking Test Procedure for Simple and Reliable Estimation of Soft White Wheat Quality. AACC International, Inc 89 (2).

Czernohorsky, J.H. and Hooker, R. 2008. The Chemistry of Baking. www.nzic.org.nz. Tanggal akses: 29/03/2018

Direktorat Gizi Departemen Kesehatan RI. 1981. Daftar Komposisi Bahan Makanan. Bhratara Karya Aksara. Jakarta

Ginting, M. H.S., R. Hasibuan, R.F. Sinaga, G. Ginting. 2014. Pengaruh Variasi Temperatur Gelatinisasi Pati terhadap Sifat Kekuatan Tarik dan Pemanjangan pada saat Putus Bioplastik Pati Umbi Talas. Seminar Nasional Sains dan Teknologi 2014. Fakultas Teknik Universitas Muhammadiyah, Jakarta.

Harzau, H., T. Estiasih. 2013. Karakteristik Cookies Umbi Inferior Uwi Putih (Kajian Proporsi Tepung Uwi: Pati Jagung dan Penambahan Margarin). Jurnal Pangan dan Agroindustri $1: 1,138-147$

Hasan, V., S. Astuti, dan Susilawati. 2011. Indeks Glikemik dari Umbi Garut, Suweg, dan Singkong. Jurnal Teknologi Industri dan Hasil Pertanian 16:1, 34-50.

Immaningsih, N. M. R. Maulana, R. Budiasih. 2012. Karakteristik Fisik dan Kimia Rimpang dan Pati Garut (Marantha Arundinaceae L.) pada Berbagai Umur Panen. Proceeding Seminar Nasional Kedaulatan Pangan dan Energi. Fakultas Pertanian Universitas Trunojoyo, Madura.

Issutarti. 2006. Pengaruh Penggunaan Lemak terhadap Sifat Fisik dan Organoleptik Chiffon Cake. TIBBS 1:1, 12-23

Kementerian Pertanian Republik Indonesia. 2015. Rencana Strategis Kementerian Pertanian Tahun 2015-2019. PERATURAN MENTERI PERTANIAN REPUBLIK INDONESIA NOMOR 19/Permentan/HK.140/4/2015 
Ladamay, N. A. dan Yuwono, S. S. 2014. Pemanfaatan Bahan Lokal dalam Pembuatan Foodbars (Kajian Rasio Tapioka : Tepung Kacang Hijau dan Proporsi CMC). Jurnal Pangan Dan Agroindustri 2:1, 67-78.

Lau, N.M., Green P.H.R., Taylor A.K. 2013. Markers of Celiac Disease and Gluten Sensitivity in Children with Autism. PLOS One 8:6, e66155

Mudjisihono, R. S.J. Munarso, Z. Noor. 2003. Pengaruh Penambahan Tepung Kacang Hijau dan Gliseril Monostearat pada Tepung Jagung terhadap Sifat Fisik dan Organoleptik Roti Tawar yang Dihasilkan. Agritech 13:4,1-6

Murdani, H. 2010. Rahasia Membuat Roti Manis. Demedia Pustaka. Jakarta.

Pomeranz, Y. dan Shellenberger. 2001. Bread Science and Technology. AVI publishing Co. Inc. Westport. Connecticut.

Ratnawati, I., 2003. Pengayakan Kandungan $\beta$-karoten Mie Ubi Kayu dengan Tepung Labu Kuning (Curcubita maxima Dutchenes). Fakultas Teknologi Pertanian, Universitas Gajah Mada. Yogyakarta.

Romanof, A.L., A.J. Romanoff. 1993. The Avian Egg. New York: John Wiley and Sons, Inc.

Rumini, E. 2010. Pengaruh Jumlah Kuning Telur terhadap Karakteristik Sponge Cake. Fakultas Teknologi Pertanian. Institut Pertanian Bogor. Bogor.

Sudaryati. 2013. Kualitas Telur. Penebar Swadaya. Jakarta.

Suhardjito. 2003. Pastry dalam Perhotelan. Andi. Yogyakarta.

USDA. 2016. USDA National Nutrient Database For Standard Reference. Full Report: 18134, Cake, sponge, prepared from recipe.http://www.ndb.nal.usda.gov. Tanggal akses: 01/07/2017

Wang, X. Bo, J. Bridges, T. Dugan, K.D. Pan, T.C. Chodosh, L.A. Montell, D.J. 2006. Analysis of Cell Migration Using Whole-Genome Expression Profiling of Migratory Cells in the Drosophila Ovary. Dev. Cell 10:4, 483-495

Winarno, F. G. 2002. Ilmu Pangan dan Gizi. Gramedia Pustaka Utama. Jakarta. 